\title{
Operationalization and Measurement of Social-Ecological Resilience: A Systematic Review
}

\author{
Cristina González-Quintero ${ }^{1}$ and V. Sophie Avila-Foucat ${ }^{2}, *(\mathbb{D}$ \\ 1 Posgrado en Ciencias de la Sostenibilidad, Instituto de Investigaciones Económicas, \\ Universidad Nacional Autónoma de México, Avenida Universidad 3000, Mexico City 04510, Mexico; \\ cristina.goqui@gmail.com \\ 2 Instituto de Investigaciones Económicas, Laboratorio Nacional de Resiliencia Costera, \\ Universidad Nacional Autónoma de México, Avenida Universidad 3000, Mexico City 04510, Mexico \\ * Correspondence: savila_1@yahoo.com.mx or savila@iiec.unam.mx
}

Received: 30 July 2019; Accepted: 21 October 2019; Published: 1 November 2019

\begin{abstract}
Academics and practitioners have become more interested in the operationalization and measurement of social-ecological resilience. An analysis of how social-ecological resilience has been operationalized and measured is crucial to understanding systems complexity and dynamics and for clarifying empirical cases of monitoring programmes in ways that enrich their utility and explanatory power. The literature shows that social-ecological resilience has been operationalized using the concepts of adaptability and absorption of disturbance. In addition, diversity and connectivity are principles that have been studied. Climate change in rural coastal regions is the most common stressor that has been studied, and the human dimension of such systems is the dominant focus. Systems interactions, feedbacks and thresholds are rarely identified or assessed. In addition, attributes of the system primarily using indicators are preferred over analysing causal relationships with models. Answering the question of what this resilience is for is a very important aspect of defining the system and the method for assessing resilience.
\end{abstract}

Keywords: resilience operationalization; resilience measurement; social-ecological resilience

\section{Introduction}

Social-ecological systems resilience is a topic of interest for academics and practitioners due to the extensive and rapid global changes and other stressors that threaten both ecosystem services and human well-being [1]. Helping stakeholders assess the current resilience status of their systems is crucial for better decision making and monitoring of desired goals [2], especially since the stressors that these systems face are so uncertain. Hence, understanding the advantages of different resilience measurements and approaches could enrich the theory and practice of social-ecological resilience.

Social-ecological systems (SESs) are complex and dynamic, and their resilience is defined as "the capacity of a system to absorb disturbance and reorganize while undergoing a change to still retain essentially the same function, structure, identity, and feedbacks" [3] (p. 6). The absorption of a disturbance is the amount of change that a system can absorb without changing to a different state [4], and reorganization is the internal control capability of the system to respond [5] or, in other words, the adjustment of the system through the interaction between components [6]. Following these definitions, a system is resilient if it can absorb and reorganize. This capacity in turn depends on the system retaining its function, structure, identity and feedbacks as a condition or attributes. Additionally, adaptability and transformability are also key attributes that influence resilience and can be used to help to understand system dynamics. Adaptability is the capacity of actors in a system to influence resilience $[3,7]$ by learning, sharing knowledge, and adjusting responses and institutions [8]. 
Moreover, transformability is the capacity to transform into a new system without becoming trapped in an undesirable situation [3]. In addition, current approaches to enhancing resilience include principles such as maintaining diversity and redundancy; managing connectivity; managing slow variables and feedbacks; fostering and understanding SESs as complex adaptive systems; encouraging learning and experimentation; broadening participation; and promoting polycentric governance systems. Diversity and redundancy are important because they can provide options for responding to changes and disturbances. Connectivity "refers to the structure and strength with which resources, species, and social actors disperse, migrate, or interact across patches, habitats, or social domains" [1]. High connectivity may help with recovery after disturbances. Slow variables can shift the system from one regime to another, which means that a critical threshold has been crossed and that a different set of feedbacks, function, and structure become a new system, losing the original identity. Such variables are slow in the sense that they change much more gradually than other fast variables [9]. Adaptive management, adaptability, and polycentric governance are also some of the principles that allow the system to learn and be dynamic.

The conceptual elements described previously are used as dependent variables to measure SES resilience or as attributes of a system to reach resilience (independent variables). The literature shows a diversity of these metrics, and it is worth studying how they are operationalized (the variables used) and measured (the methods). The measurement of social-ecological resilience is essential for making sense of broad patterns and identifying emergent properties in complex systems [10]. Furthermore, the estimation of resilience and its transition from theory to practice requires assessment [11] to implement better strategies to buffer or respond to changes [12].

An equally important objective is to identify SES stressors and shocks (as encapsulated by the question, resilience to what?) $[13,14]$. Shocks are perturbations that are characterized by a peak pressure that is beyond the normal range of variability in which the system operates [15]; they are infrequent, sudden and generally unpredictable events [16] that tend to start intensely and have dramatic effects [17]. Stressors, in contrast, are continuous pressures that usually increase slowly within the normal range of variability that resides in the system but have a cumulative effect $[15,18]$ that causes the system to shift. Shocks and stressors affect SES dynamics and regime shifts depending on their resilience. Socioeconomic, political or environmental disturbances can affect SESs, and climate change effects, such as droughts, hurricanes, and flooding, have recently been a topic of interest. Thus, it is relevant to observe which kinds of disturbances were assessed in the literature.

In the last decade, there has been an increase in social-ecological resilience operationalization and its measurement, but despite this great interest, the literature suggests that this area of study still faces some challenges. The main difficulties in translating the concept of resilience into useful variables and metrics is the complex dynamics that form due to the diversity of these processes and the interaction of fast and slow variables in social and ecological systems [8]. In addition, identifying the thresholds for multiple shocks and stressors [19] and delineating the system integration and interdependencies between social and ecological components remains challenging [11]. Moreover, the different interpretations of the concept, often linked to the theoretical framework that is used, creates confusion in its empirical application. Therefore, some academics showed that resilience can be estimated by theoretical approximations [20] that are not observed directly and are instead inferred [11].

As a result, a literature review on how social-ecological resilience has been operationalized and measured is needed to understand how the dynamics of SESs have been addressed [8] and whether there is a consistent way to monitor SES progress [21]. Consequently, the aim of this paper is to bring some clarity to the ways that social-ecological resilience has been empirically analysed so that it can be used in ways that enrich its utility and explanatory power. This need is met by providing an overview of the conceptual elements that are used for the operationalization of resilience, the variables that configure the system under study, the disturbances that are of interest, and the methods that have been used to estimate resilience. 


\section{Materials and Methods}

\subsection{Literature Selection Process}

The literature was retrieved from two search platforms: Web of Science and Google Scholar. Furthermore, from the articles that were selected, the key references related to the operationalization and measurement of social-ecological resilience were identified. The time period of the publications was from 2005 to the beginning of 2017, since a special issue on theoretical surrogates was published in the journal Ecosystems in 2005, which initiated the empirical study of the concept. Over the study period, publications on this topic were scarce until an increase occurred in 2012.

To identify papers that assess or measure social-ecological resilience, the search was restricted first by the topic "social-ecological resilience" $(n=1888)$ (Figure 1). The next filter was the word "resilience" in the title $(n=704)$, since resilience is often part of the discussion but is not operationalized or measured because that is not the aim of the papers. Then, from those 704 articles, the next step was to search for the keywords "resilience measurement," "resilience model," "resilience indicators," and "resilience assessment" ( $n=322)$ to identify papers in which intent is to analyse how resilience is operationalized and measured. Then, the text was screened to identify the studies that mentioned explicitly the concept of social-ecological resilience within their theoretical framework $(n=130)$. Finally, studies were checked in detail to identify those with both social and environmental variables, as the social-ecological resilience approach implies that either a social or ecological system cannot be considered in the absence of the other [22]. At the end of the selection process, a total of 50 studies were selected for review. Those comprised peer-reviewed literature and non-peer-reviewed literature, such as journal articles, conference papers, working papers, and theses. Non-peer-reviewed articles were important to include since some relevant studies were made, especially by international organisation; however, the majority are peer-review literature. The papers that were selected were written in Spanish and in English. 


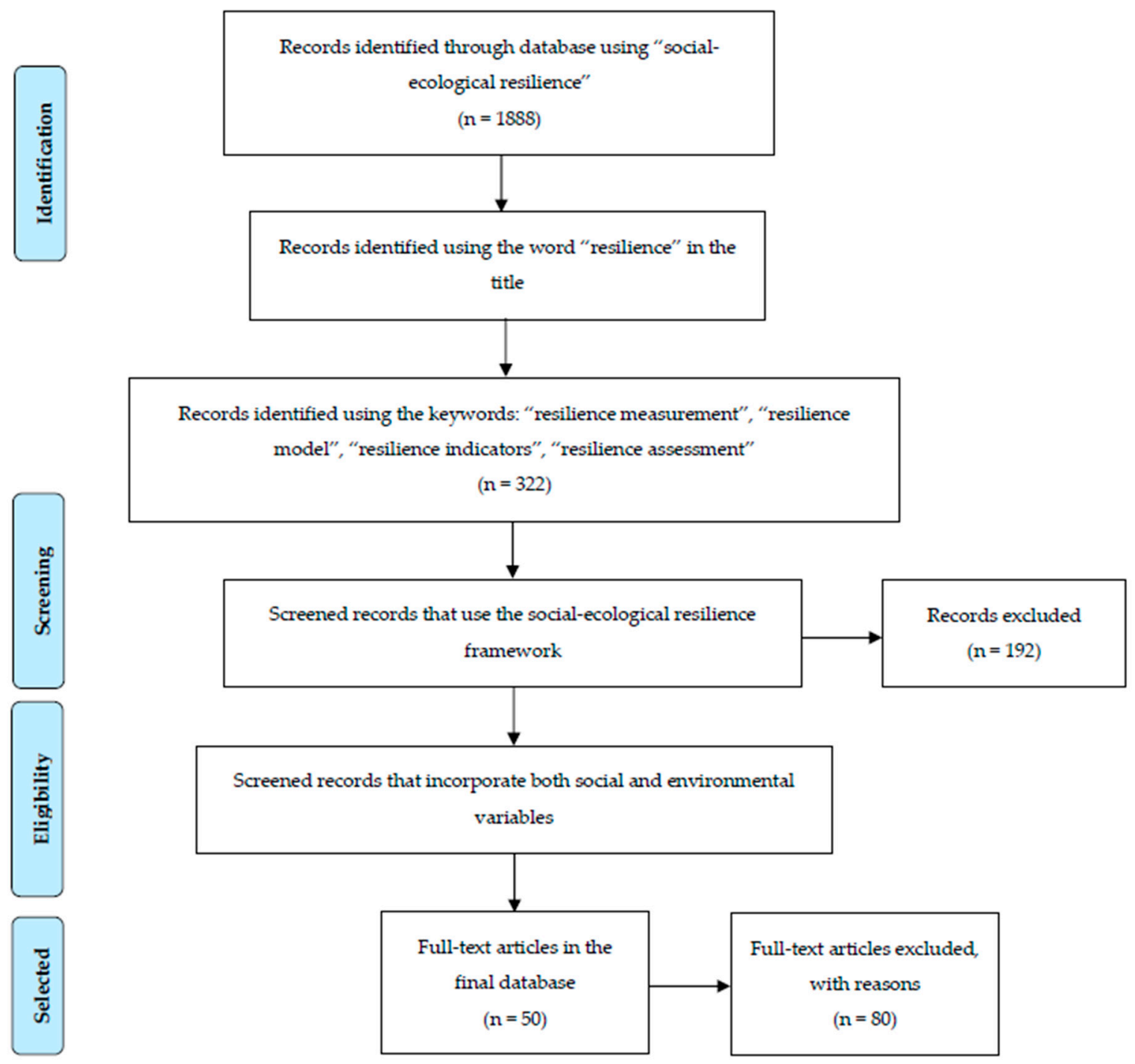

Figure 1. Literature selection process. Flow diagram based on PRISMA.

\subsection{Review Process and Theoretical Foundations}

A deeper analysis of each study was performed to compile a database in Excel. Statistical analysis of the topics of interest was carried on. The topics are related to the operationalization of social-ecological resilience, such as the conceptual elements, the characteristics of the system and the disturbances of interest, and to the measurement of resilience by a models or by indicators (Figure 2).

First, the conceptual elements that the studies measured or assessed were identified, such as absorption of disturbance, system identity, reorganization, adaptability, and transformability.

Second, principles for enhancing social-ecological resilience were identified as proposed by Biggs et al. (2012) [1], based on their ability to improve the resilience of critical ecosystem services for human well-being in the face of a disturbance [8]. These principles include the ability to maintain diversity and redundancy, manage connectivity, manage slow variables and feedbacks, foster an understanding of SESs as complex adaptive systems, encourage learning and experimentation, broaden participation, and promote polycentric governance systems. To classify them we searched in the studies when they addressed them. For example, if the study included biodiversity or livelihood diversification this was taken as a diversity measure of the system. Although the studies did not explicitly mention Biggs framework, we considered the variables they measure. 

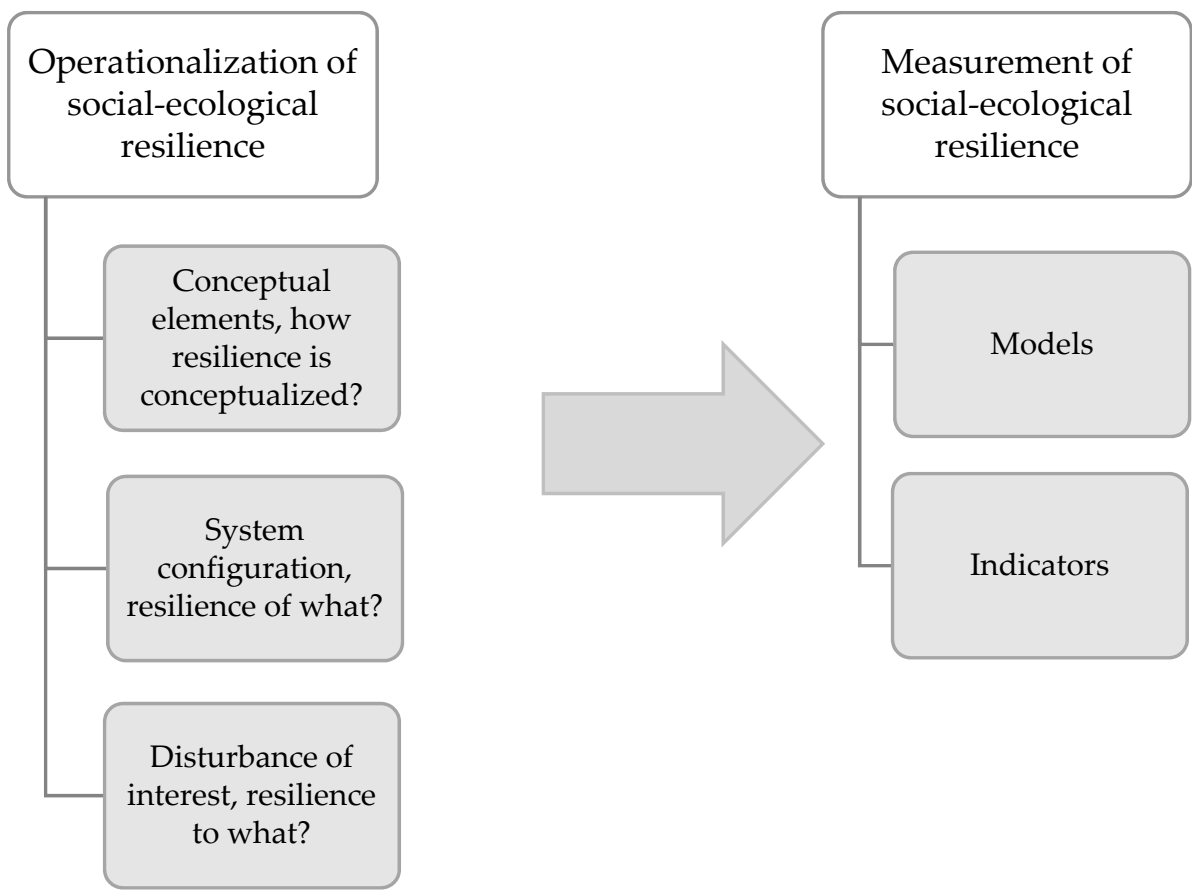

Figure 2. Features of the analysis.

Third, to try to understand the system configuration (resilience of what?), the variables characterizing the social and environmental components of the system were identified. The variables of the social subsystem were divided into social, economic, human and infrastructure variables. The variables related to the characteristics of the people who live and influence the system are the human variables. The social variables explain the relations among the people in the system and their participation in formal and informal networks, groups and institutions, and these variables also incorporate the relationship between human use and the environmental subsystem [23]. The economic variables are the availability of money through income, savings, and loans [24]. The infrastructure variables are related to house conditions such as electricity and drainage and to roads and telecommunication as important assets for economic activities [23]. The variables of the environmental subsystem were divided into abiotic, ecosystem, natural resources, and environmental management variables. The natural resource variables comprise direct-use resources that are co-produced by the interaction of the social and environmental subsystems [25]. The abiotic and ecosystem variables reflect the essential processes and functions of the environmental subsystem [21] that allow natural resources to be provided. Finally, the variables of environmental management are related to the management of the environmental subsystem.

Then, to answer the question of what the system is resilient against, the shocks and stressors that affect the system were identified in the literature.

Finally, the methods used to estimate resilience were defined and grouped in models and indicators depending on how the studies approached them.

\section{Results and Discussion}

\subsection{Operationalization of Social-Ecological Resilience}

\subsubsection{Conceptual Elements}

It is necessary to clarify how resilience is conceptualized by explicitly defining the conceptual elements that are to be addressed [10] to know what is being measured and to delineate the changes that have been observed in reality from the theoretical ones [26]. 
The results show that the main concepts used are absorption and adaptability of disturbance (Table 1), followed by reorganization, transformability, and system identity. Usually, the studies simultaneously assessed more than one element, such as the absorption of a disturbance and its identity. Absorption and reorganization are the key elements for measuring resilience; however, adaptability, which is a social element that influences resilience, is the second most studied factor.

Table 1. Conceptual elements of resilience.

\begin{tabular}{cc}
\hline Conceptual Elements of Resilience & $\%$ \\
\hline Absorption of disturbance & 68 \\
System identity, structure, and function & 16 \\
Reorganization & 28 \\
Adaptability & 66 \\
Transformability & 16 \\
\hline
\end{tabular}

The absorption of a disturbance is one of the main elements in the measurement of resilience, as proposed by Holling in 1973 [27]; thus, this concept is well internalized in the literature and is relatively easy to understand and operationalize. However, as explained further in the text, there are different ways to measure absorption depending on the epistemological and ontological backgrounds. For example, absorption is operationalized in a system by factors such as access to land by rural populations since it provides flexibility in the selection of crops as an alternative to confront stress [28]. In addition, Altieri and Nicholls (2013) [29] used the maintenance of agricultural production of food in agroecosystems despite drought or storm as proxies of absorption. In contrast, Wang, Huang, and Budd (2012) [30] estimated absorption by the factors that determine whether land can absorb precipitation and maintain its original state.

Reorganization is also used in the literature but is mainly related to social variables, such as reconfiguration of institutional relations and arrangements. In that sense, cooperation, networks, participation, trust, and reciprocity are core variables for this conceptual element [31].

Adaptability is also used in the literature and has been especially linked to climate change [32]. This shows that the literature on risk has considered the social-ecological resilience framework and the overlapping of concepts, which can result in a misunderstanding of how to operationalize social-ecological resilience. Because adaptability refers to the role of human action, it is operationalized by using community actions for learning $[18,33,34]$ or changing. For example, changes in livelihood strategies are considered mechanisms of adaptability $[17,35,36]$. Changes in agricultural, fisheries, and forestry practices that have been adopted and improved by communities due to past experiences with disturbances are indicators of adaptability [37].

In contrast, system identity, structure, and function are conceptual elements that are more difficult to measure and conceptualize in SESs; thus, further efforts are needed in that sense. Similarly, transformability is one of the lesser-studied elements, probably because this concept is confused with transformation and because it is difficult to define the variables that measure the capacity to not stay in a trap.

Therefore, there is interest in the literature in assessing the role of human actions on the system rather than studying the attributes of other systems.

Regarding the seven principles of Biggs et al. (2012) [1] for enhancing resilience (Table S1), only $6 \%$ of the publications that applied this conceptual framework explicitly mentioned them, and $90 \%$ measured some of the principles without mentioning this framework. The findings show that $60 \%$ of the papers measured diversity in social and environmental subsystems (Table 2). Some examples of the variables of diversity in the environmental subsystem are genetic traits in local varieties of crops and animal breeds that provide tolerance to drought, frost, salinity, pests, and diseases [37]. In the social subsystem, diversity refers to the diversity of productive activities [34], which is a strategy 
for maintaining resources and income with different risks [38]. Diversity is an attribute that can be operationalized in both subsystems and is crucial for absorption and reorganization [8].

Table 2. Principles to enhance the operationalization of resilience.

\begin{tabular}{|c|c|c|c|}
\hline $\begin{array}{l}\text { Principles to Enhance } \\
\text { Resilience }\end{array}$ & $\begin{array}{l}\text { Variables Used in the } \\
\text { Environmental Subsystem }\end{array}$ & $\begin{array}{l}\text { Variables Used in the Social } \\
\text { Subsystem }\end{array}$ & $\%$ \\
\hline $\begin{array}{l}\text { Diversity and } \\
\text { Redundancy }\end{array}$ & $\begin{array}{l}\text { Biodiversity, spatial heterogeneity, } \\
\text { diversity and redundancy of the } \\
\text { ecosystem, diversity of land use, } \\
\text { and diversity of the base } \\
\text { of resources }\end{array}$ & $\begin{array}{l}\text { Diversity of decision makers, } \\
\text { investment in diversity of } \\
\text { response, social diversity, } \\
\text { diversification of productive } \\
\text { activities, specialization index, } \\
\text { diversity, redundancy, } \\
\text { and infrastructure flexibility }\end{array}$ & 60 \\
\hline Connectivity & $\begin{array}{l}\text { Pollination, seed dispersal, presence } \\
\text { of wildlife corridors and networks, } \\
\text { flow of regeneration, and ecological } \\
\text { interactions between different } \\
\text { landscape elements }\end{array}$ & $\begin{array}{l}\text { Social networks, } \\
\text { communication, changes in } \\
\text { migration, membership in social } \\
\text { groups, potential for access or } \\
\text { evacuation, communication } \\
\text { capacity and modularity of } \\
\text { infrastructure, distance to urban } \\
\text { areas and markets, and mobility }\end{array}$ & 50 \\
\hline $\begin{array}{l}\text { Slow Variables and } \\
\text { Feedback }\end{array}$ & $\begin{array}{l}\text { Soil acidity, depth of water table and } \\
\text { salinized area, vegetation cover, } \\
\text { level of agrochemical use, } \\
\text { and effectiveness of irrigation } \\
\text { infrastructure }\end{array}$ & $\begin{array}{l}\text { Financial viability, size of the } \\
\text { dairy and fruit processing sector, } \\
\text { and increase in food insecurity }\end{array}$ & 20 \\
\hline $\begin{array}{l}\text { Learning and } \\
\text { Experimentation }\end{array}$ & & $\begin{array}{l}\text { Learning from past } \\
\text { contingencies, experimentation, } \\
\text { training, innovation, } \\
\text { and education }\end{array}$ & 36 \\
\hline Participation & & $\begin{array}{l}\text { Patrolling for illegal activities, } \\
\text { decision making through } \\
\text { dialogue, participation in } \\
\text { activities, collective action, } \\
\text { organization, agent access to } \\
\text { information, power relations, } \\
\text { and cooperation }\end{array}$ & 32 \\
\hline Polycentric Governance & & $\begin{array}{l}\text { Decentralization, governance } \\
\text { performance, local } \\
\text { interdependence and global } \\
\text { autonomy, and cross-scale } \\
\text { institutions }\end{array}$ & 20 \\
\hline $\begin{array}{l}\text { Understanding of } \\
\text { Social-Ecological } \\
\text { Systems as Complex } \\
\text { Adaptive Systems }\end{array}$ & & $\begin{array}{l}\text { Acknowledgement of slow } \\
\text { variables }\end{array}$ & 2 \\
\hline
\end{tabular}

Connectivity variables are also among the most studied and are considered in both subsystems by $50 \%$ of the publications. These variables are studied because if the SES is well connected, they can accelerate the restoration of disturbed areas, the maintenance of biodiversity, and communication among social groups [1]. For example, networks and ties within and outside the community can significantly strengthen the community's ability to contain disturbances, and strong social ties within the community can enable [39] self-organization [31].

The next most commonly used variable is learning, which was considered in $36 \%$ of the publications. Learning ensures that individuals and institutions can use new skills and technologies to adapt [34] or transform [1]. This capacity implies that the system incorporates previous experiences in collective actions and therefore has a memory [31]. Participation, which was studied by $32 \%$ of publications, 
primarily works as a facilitation mechanism that promotes learning capacity and collective action in response to disturbances and changes in the system [40]. Furthermore, participation allows for the formation of connections and the self-organization of decisions [41]. Both principles are mainly studied within the social subsystem and are associated with adaptability.

Slow variables and feedback were two of the less addressed principles and were only discussed in $20 \%$ of the publications. Slow variables represent the key variables of the system, and if a certain threshold is attained in those variables, the system can be transformed. The use of this type of variable implies a profound knowledge of the system structure and dynamics, and the identification of slow variables requires a knowledge of and a previous study of the system. Moreover, many times the slow variable is identified once the threshold is attained. Although we already know the slow variables for some systems, such as water quality, eutrophication, or social conflict, the variables for other SESs are not easily identified. Similarly, SES interactions and feedbacks are generally not identified in the studies because the systems are not well delimited. Understanding SESs as complex adaptive systems was only noted by Nemec et al. (2014) [42], and they exemplify it with the variable called 'acknowledgement of slow variables'. Knowing which are the slow controlling variables associated with thresholds in the system leads to the application of adaptive management actions and the incorporation into the long-term governance of SESs, increasing resilience.

Finally, polycentric governance enables the other resilience-enhancing principles [8]. This concept refers to multiple centres of decision making at different scales; in other words, horizontality of decision making that is expressed in terms of modularity and functional redundancy can preserve key social-ecological elements in the face of disturbances and change [1,42]. Governance creates conditions for collective action that constitute the social system's institutions and strongly influences the ability of SESs to respond to disturbances [43]. Decentralization of power and the resources necessary to govern make the system more adaptable than a hierarchical system because monitoring, actions, and resources are located close to the origin of the problems [21]. However, there are other forms of governance that allow the system to respond, such as adaptive governance, and the assessment of the diverse forms of social capital is very important.

\subsubsection{System Configuration of Resilience}

System configuration is linked with the question "resilience of what?" (Table S1), i.e., which are the key components of SESs that are relevant to study [12]. According to Resilience Alliance (2010) [12], the ideal way to approach the complexity of measuring social-ecological resilience is to define the study system based on the interacting environmental and social variables. However, only $24 \%$ of publications define the interaction between variables and their dynamics. Most of the studies analysed use social and environmental dimensions but not their interactions; this means that they do not define the dynamics of the system but rather the elements enhancing resilience. Describing social-ecological interactions is complicated because some of the interactions between variables operate at different temporal and spatial scales [44].

On average, in each study, the ecological subsystem had 8 ecological variables, whereas the social subsystem had 16 variables distributed homogenously among social, human, economic, and infrastructure variables. Within the social subsystem (Table 3), the human and social variables were the most studied (78\%). Education was commonly measured because it facilitates the capacity for change [19] and makes societies more adaptable [21], in human variables. Social variables where institutions and organizations are the most common variables because they provide the potential to generate a constructive change after a disturbance [28]. Additionally, economic variables were widely used because income is generally related to economic well-being and food security [31]. Additionally, savings or borrowing money at the household level can be used to recover from disturbances [21]. Finally, the infrastructure variables were studied by $52 \%$ of the publications; in particular, electricity, drainage, and other public services are crucial because the interruption of these essential services leads to poor rescue and relief operations [39]. 
Table 3. Variables of the social subsystem.

\begin{tabular}{ccc}
\hline Type of Variable & Examples of Social Subsystem Variables & $\%$ \\
\hline Social & $\begin{array}{c}\text { Land tenure regimes, policies, laws, equity, trust, } \\
\text { security, leadership, reciprocity, legitimacy, and culture }\end{array}$ & 78 \\
\hline Economic & $\begin{array}{c}\text { Earnings, savings, market, financial viability, sources of } \\
\text { income, expenses, economically dependent people, } \\
\text { and financing }\end{array}$ & 76 \\
\hline Human & $\begin{array}{c}\text { Users of resources, skills, knowledge, food security, } \\
\text { values, years of formal study, health, age, gender, } \\
\text { experiences, and well-being }\end{array}$ & 78 \\
\hline Infrastructure & $\begin{array}{c}\text { Infrastructure at the household and community levels, } \\
\text { boats for fishing, equipment, irrigation channels, water } \\
\text { supply, roads, and transportation }\end{array}$ & 52 \\
\hline
\end{tabular}

The ecological subsystem is operationalized in $70 \%$ of the publications based on variables describing the use of natural resources. This is very important because these variables represent feedbacks between social and environmental subsystems. Additionally, $48 \%$ of the publications considered whether the environmental subsystem was under some type of protection or was managed in some way. As such, these variables are focused on the context of natural resource management and the characteristics of the environment that shape them. Another interesting finding is that abiotic (58\%) and ecosystem $(64 \%)$ variables are considered (Table 4 ) in almost the same proportion.

Table 4. Variables of the environmental subsystem.

\begin{tabular}{ccc}
\hline Type of Variable & Examples of Environmental Subsystem Variables & $\%$ \\
\hline Abiotic & $\begin{array}{c}\text { Percent humidity, climate, hydrological processes } \\
\text { and properties, soil acidity, depth of water table, } \\
\text { and slope gradient }\end{array}$ & 58 \\
\hline Ecosystem & $\begin{array}{c}\text { General characteristics of the vegetation, proximity } \\
\text { to forests, forest area, key ecological processes, } \\
\text { and ecosystem conditions }\end{array}$ & 64 \\
\hline Enviral Resources & $\begin{array}{c}\text { Stock resources, such as fish, water, trees, livestock, } \\
\text { crops, and firewood }\end{array}$ & 70 \\
\hline & $\begin{array}{c}\text { Protection of the forest near the community, } \\
\text { creation of fish sanctuaries, ecological } \\
\text { sustainability, investment and soil conservation } \\
\text { practices, afforestation, sustainable management of } \\
\text { resources, environmental safeguard measures, } \\
\text { and natural protected areas }\end{array}$ & 48 \\
\hline
\end{tabular}

The results show that the social dimension of SESs has been studied with a larger diversity of variables than the ecological dimension. Furthermore, in the ecological subsystem, the most studied variables are those that are related to the human use of natural resources. This might be because, in the social system, more proxies can be generated to explain different processes. In contrast, to obtain information from the environmental subsystem, direct measurements must be made (which might also be more expensive), such as measuring soil acidity, unless these variables are evaluated based on social perceptions. In addition, to conduct resilience research and obtain information on the entire system, interdisciplinary groups are needed [44], but not all of the papers incorporated this approach. Moreover, as mentioned before, if the system interactions are not described, it is expected that one subsystem is prioritized over the others, depending on the research group and objectives. 


\subsubsection{Resilience to Disturbances of Interest}

The identification of the particular disturbances that the system is coping with is associated with the question "resilience to what" [12] (Table S1). A total of 78\% of the studies in the literature were case studies that were primarily located in rural coastal populations in developing countries (Figure 3).

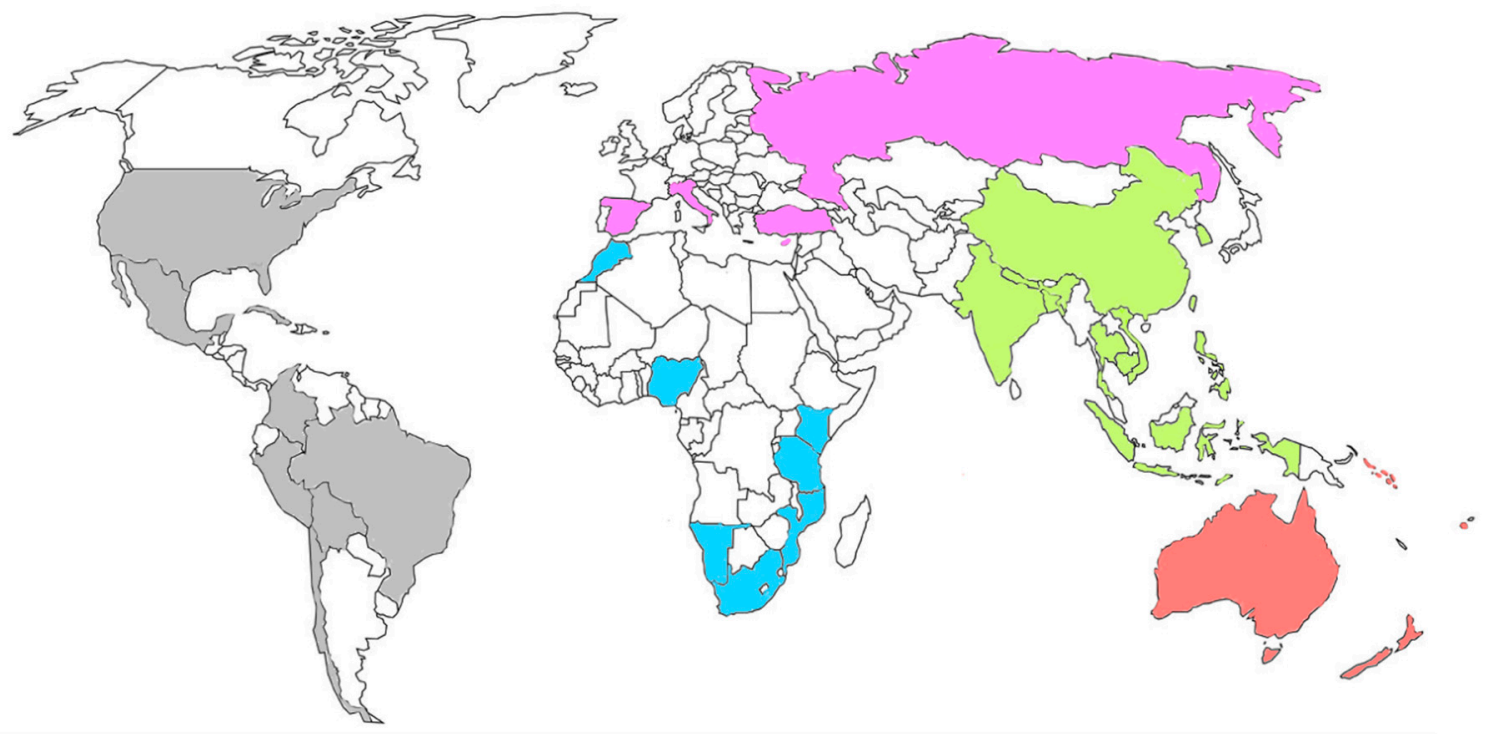

Figure 3. Distribution of study cases in each continent. In grey are the countries where study cases took place in America, in blue those in Africa, in pink those in Europe, in green those in Asia and in red those in Oceania.

These regions are prioritized because international climate change research identifies them as very vulnerable regions due to heavy rainfall, floods, sea level rise, and coastal erosion [45]. In fact, climate change is one of the most commonly mentioned stressors and shocks in such regions. Rural populations are affected because their livelihoods directly depend on natural resources [46]; in addition, they tend to be socio-economically and geographically isolated, which poses a challenge for the provision of public services and institutional development [47].

Regarding the disturbances that the publications studied, 39\% evaluated stressor effects, $27 \%$ evaluated shocks, and a surprising $33 \%$ evaluated both types. Nevertheless, only a few publications $[17,33,48,49]$ explicitly addressed them as stressors or shocks that could be conceptually identified by the social-ecological literature. The relevance of differentiating between the two types of disturbance is that their effects in a system might be different because shocks are generally external events, and as researchers, we often decide what kind of disturbance to study instead of assessing the most important one for the system. Interestingly, stressors are more commonly assessed in the socioeconomic dimension, whereas shocks are more commonly assessed in the biophysical dimension (Table 5). This difference might be because social processes can be described using qualitative information through human perception or oral histories, whereas biophysical monitoring involves infrastructure and the collection of data. 
Table 5. Types of disturbances addressed by publications.

\begin{tabular}{|c|c|c|}
\hline Type of Disturbance & Stressors & Shocks \\
\hline Biophysical & $\begin{array}{l}\text { Climate change, declining resources, } \\
\text { land degradation, biodiversity loss, } \\
\text { dry and cold environment, } \\
\text { and declining catch rates }\end{array}$ & $\begin{array}{l}\text { Forest fire, monsoon, diseases, } \\
\text { tsunami, earthquake, typhoon, } \\
\text { hurricane, cyclone, drought, tidal } \\
\text { flooding, and flooding }\end{array}$ \\
\hline$\%$ & $48 \%$ & $54 \%$ \\
\hline Socioeconomic & $\begin{array}{l}\text { Infrastructure development, being at } \\
\text { the mercy of the market, chronic poor } \\
\text { health, influx of industrial labour } \\
\text { migrants, slave trade, diminished } \\
\text { terms of trade, ageing population, } \\
\text { increased industrialization, changes in } \\
\text { markets, establishment of protected } \\
\text { area, high food prices, threats of } \\
\text { community relocation and lawsuits, } \\
\text { incentive programmes for large-scale } \\
\text { fishing, change in politic capital, } \\
\text { and increased urbanization }\end{array}$ & $\begin{array}{l}\text { Damaged boats, ethnic conflict, } \\
\text { face cost of funerals, price } \\
\text { volatility, technological failure, } \\
\text { border closing, charcoal ban, } \\
\text { and the fall of Soviet Union }\end{array}$ \\
\hline$\%$ & $43 \%$ & $21 \%$ \\
\hline
\end{tabular}

\subsection{Resilience Measurement}

The literature review shows that two types of generic measurements were performed, one using models and the second using indicators, and both were assessed on different timescales. Qualitative and quantitative methods were used in $60 \%$ of the publications, only qualitative methods were applied in $17 \%$, and only quantitative methods were applied in $23 \%$. Social-ecological resilience is complex, and a combination of methods can explain the phenomenon in a more complete way.

\subsubsection{Models}

Dynamic models try to capture system complexity, the state and control variables, the thresholds, and the feedbacks between the ecological and the social subsystems. These variables can be measured with a dynamic time series that calculates the equilibrium and the size of the region of interest [13] given the configuration of the system [50]. Models measure how the system responds to a change in relation to a threshold and the relative state of the system to that threshold [51]. In other words, they try to predict the loss of resilience, given specific thresholds. The results show that $18 \%$ of the articles revised present dynamic models and that the majority of these models are conceptual models. Bueno and Basurto (2009) [52] measured the resilience of a fishing system through system dynamics using VENSIM software, in which the loss of resilience occurs when a state variable of the system crosses a critical quantitative threshold. In general, papers using modelling are based on the exploitation of a resource stock by methods such as fishing [52], forest management [53], and agricultural production [54]. However, Kim et al. (2017) [55] also assessed modelling by addressing three issues that they identified in their study area: coastal landscape management, agricultural structure, and tourism industry structure. This method provides a way to test the system for tipping points without putting the actual system at risk [56]. Dynamic models also incorporate qualitative approaches to collect the data and build the system through activities such as focus groups [53] and participative workshops [51].

Dynamic models are not generally applied empirically because the threshold information is not always available; that is, a historical analysis of the dynamics of the SES when it crosses thresholds may not exist. In addition, the feedback between the systems is not always traceable. For this reason, the measurement of resilience through models has been so complex that it is not possible to put it into practice; therefore, they are difficult to communicate and implement in decision making processes. 
Multivariate models were applied by $24 \%$ of the publications. This type of model was used for two purposes. First, it was used to analyse the significance of certain variables that enhance resilience. For example, Schwarz et al. (2011) [33] demonstrated that community participation, support, and leadership are positively related to coping and learning from stress. Another example is the work of Eakin et al. (2012) [28], who attempted to relate household characteristics, such as lot size, location, occupation, and diversification, to the impact of a hurricane. Second, multivariate models are used to develop scenarios of system changes. Saxena et al. (2016) [57] analysed how shocks and stressors influence household livelihood strategies and how income is affected. Rasch et al. (2017) [56] measured how the variables of inequality and vegetation cover change within three scenarios involving shocks and stressors. Some of the works also estimate thresholds; for example, Dearing (2008) [58] and Forbes (2009) [59] measured thresholds retrospectively through historical analysis of their study areas. Therefore, the measurement by means of multivariate models explains and tests the characteristics of the system that contributed to its resilience and how certain variables can be affected by and can react to shocks and stressors in different scenarios. These models incorporate interviews, surveys, and participative observation, not only as data collection but also to explain the results $[28,33,57,60]$.

\subsubsection{Indicators}

Social-ecological resilience variables were assessed using indicators in $36 \%$ of publications. Uy et al. (2011) [61] quantified the level of livelihood assets using a scale from 1 to 5 ( 5 being the highest and 1 being the lowest), and households with the highest level of assets were considered to have a high adaptive capacity. In addition, Wang et al. (2012) [30] measured three indicators of resilience-the performance of the system, the duration of the recovery, and the effort of recovery-to assess the capacity of the area to cope with typhoons. Bergamini et al. (2014) [37] evaluated the indicators that measure elements of resilience by applying a value and a trend to each indicator, where 1 is very low and 5 is very high, and the high and low trends are used to explore the direction of community development.

Indicators were also grouped into indices by $16 \%$ of the investigations. In particular, Dasgupta and Shaw (2015) [39], Kotzee and Reyers (2016) [62] and Suárez et al. (2016) [63] obtained information from censuses at the municipal level to create an index. Quaranta and Salvia (2014) [38] measured resilience through a rural diversity index that is composed of economic, social, and natural diversity under the assumption that diversity increases resilience. Montalba et al. (2013) [37] used the risk index and claimed that if the risk index is low, the resilience is high. Other publications assigned values to the indicators based on scales (very high, high, medium, low, and very low) [34].

The two forms of indicator measurement discussed above apply qualitative methods, such as participatory workshops or focus groups (Uy et al. 2011) [61], and both are used by experts or decision makers [18,19,29]. In addition, data collection is performed by surveys [33] or censuses [39].

Another type of indicator analysis only uses qualitative methods to measure resilience and does so by means of value scales (very high, high, medium, low, and very low) that represent the attributes of resilience [34]. Another way this is measured is through indicators that are based on the phases of the adaptive cycle; the presence of these indicators suggests a resilient SES, while their absence suggests loss and great vulnerability to disturbances $[16,64]$. An additional method involves historical analysis of the behaviour of systems in their response to different disturbances over time through interviews [65]. Finally, another way to measure indicators is through interviews and focus groups in order to establish the identity of the system and its tendency to cross social thresholds [36].

Most of the publications that involve indicators seek to establish the attributes that make the system resilient or to determine the status of such attributes, whereas some explain the system characteristics that need to be enhanced and track changes in these attributes. The advantage of studying resilience in this way is that these indicators can be used both for research purposes and for decision making and public communication because they condense the complexity of the systems into manageable and compact information [63]. However, caution must be exercised in summarizing complex processes with a simple metric [21]. 


\subsubsection{Timescale}

The estimation of resilience in publications can also be categorized as prospective and retrospective [57]. First, the publications that explain the processes and responses of SESs to past disturbances provide a retrospective analysis [66], whereas the publications that focus on predicting the resilience of systems to absorb disturbances in the future provide a prospective analysis [57]. In a prospective analysis, dynamic models try to predict how close a system is to thresholds and the likelihood of crossing them in the future given their configuration and the disturbance. Additionally, in a retrospective analysis, multivariate models can be used to analyse the weight that certain variables have in explaining the properties or characteristics that allowed a system to respond to disturbances in the past, whereas in a prospective analysis, multivariate models can be used to develop scenarios of system changes based on empirical data on the current state of the system and how it would react in the future to shocks and stressors. Indicators can be used to analyse SESs in two ways by studying how a disturbance in the past has affected the attributes of the system and by monitoring indicators to determine how the system would respond to disturbances in the future.

\subsection{Limitations of the Study}

Some limitations exist in this review. The publications evaluated in this study include only those with the word resilience in their title, a social-ecological resilience framework, assessment or measurement of resilience, and environmental and social variables. As a result, we excluded other possible studies that could provide good information on the operationalization and measurement of social-ecological resilience, such as Dakos et al. (2015) [67], who measured early warning of regime shifts; Moore et al. (2015) [68], who quantified network resilience; and Fleischman et al. (2010) [69], who analysed robustness in SESs over time. Additionally, the selected publications include only documents in English and Spanish, and other works in other languages were excluded. Despite the limitations, the publications selected are specific for assessing resilience measurement and provide enough information for the analysis as well as very interesting findings.

\subsection{General Trends}

The actual trend for operationalizing and measuring resilience is based on a large proportion, on assessing climate change effects in coastal regions using indicators and emphasizing social components. The large majority of the studies assess system attributes for reaching resilience rather than the system dynamics. However, determining and assessing interaction and thresholds of coupled systems is the main issue for understanding SES dynamics and trajectories. Therefore, studies need to clarify the systems structure and the interaction between components. That means that the conceptual elements of adaptability and absorption could be used for explaining changes on the system and not only being an attribute to become resilient. Similarly, Biggs (2012) [1] principles can have a positive or negative effect in the systems in terms of sustainability, therefore it would be useful to analyse the effects of those attributes in the systems. However, some challenges need to be faced such as interdisciplinary or transdisciplinary co-construction of the conceptual model, long terms research in order to establish baselines and a profound knowledge of the system for identifying possible thresholds, as well as create models for measuring interaction and processes that take place in different temporal and spatial scales. In addition to, resilience of what and to what, there is a need to clarify resilience for whom or for what, i.e., if resilience is measured for knowing better the system or if resilience is assessed for policy makers to solve a specific problem. Immediate actions are needed if resilience measurement wants to be used for reaching sustainability. Therefore, indicators and index are a useful tool for assessing general or specific resilience. However, it is important to assess resilience from a complex perspective while also keeping the measurement useful for easy communication and application. 


\section{Conclusions}

The literature shows that social-ecological resilience has been addressed mainly by operationalizing the concepts of adaptability and absorption of disturbance and that the principles of diversity and connectivity are the most commonly studied. Consequently, our review reveals the need for further research on some conceptual elements because social-ecological resilience is still interpreted differently by different groups. Our results show that the social dimension of SESs has been studied with a larger diversity of variables than the ecological dimension. Furthermore, in the ecological subsystem, the most studied variables are those that are related to human use of natural resources. In addition, studies do not describe the feedbacks between variables, so the social and ecological subsystems are not integrated. This implies that there is a gap in the methods used to address the complexity of a system. Nevertheless, finding studies that are trying to assess resilience from a system perspective has become more frequent in recent years.

Mixed methods are used in models and indicators. Although models allow for a more dynamic representation of a system and permit the identification of interactions and thresholds in a more systemic approach, most studies use indicators and indices to assess resilience. Therefore, resilience attributes, instead of causal relationships, are the main aspects that are studied. Resilience has been empirically analysed in relation to climate change in rural coastal regions, but it is important to analyse other study areas. In addition, the simultaneous study of different stressors and shocks allows a better understanding of how systems react to several disturbances at the same time, and consequently a measurement of general resilience. The previous is important since the optimization of system elements to a specific goal causes specific resilience but general resilience might decrease [22].

Finally, this study shows that the selection and application of a method depends on both the availability of the information and the research question. Is resilience being measured to know and predict the system? If this is the case, a dynamic model is a useful tool. In contrast, if resilience is measured to know which actual characteristics of a system should be strengthened, indicators are a good instrument. Thus, resilience for what is a key question, not only in terms of attributes or system dynamics but also if the measurement is linked to sustainability. Similarly, resilience for whom is a relevant question, operationalization might be different if resilience is studied for policymaking or for research purposes.

Ideally, for the conceptualization of a SES and the identification of its interactions and thresholds, there needs to be clarity in the conceptual elements used to assess resilience and in the explicit corresponding methods that vary depending on the stressor, the system, and the reason for studying resilience.

Supplementary Materials: The following are available online at http://www.mdpi.com/2071-1050/11/21/6073/s1, Table S1: Characteristics of the selected studies [70-83].

Author Contributions: C.G.-Q. and V.S.A.-F. wrote the paper together. C.G.-Q. conducted the literature search and analysed the data. V.S.A.-F. provided elements for the introduction, discussion and conclusions.

Funding: This research was funded by the UNAM (Universidad Nacional Autónoma de México) grant number UNAM-PAPIIT-IN301516, the CONACyT (Consejo Nacional de Ciencia y Tecnología) scholarship programme and the 290832 ANR-CONACYT project.

Acknowledgments: The first author gratefully acknowledges the Programme in Sustainability Science, UNAM (Posgrado en Ciencias de la Sostenibilidad, Universidad Nacional Autónoma de México). We would like to acknowledge Patricia Balvanera Levy for her comments and recommendations for this study. This work is part of the Coastal Resilience Laboratory research projects (LANRESC).

Conflicts of Interest: The authors declare no conflicts of interest. 


\section{References}

1. Biggs, R.; Schlüter, M.; Biggs, D.; Bohensky, E.L.; BurnSilver, S.; Cundill, G.; Dakos, V.; Daw, T.M.; Evans, L.S.; Kotschy, K.; et al. Toward Principles for Enhancing the Resilience of Ecosystem Services. Annu. Rev. Environ. Resour. 2012, 37, 421-448. [CrossRef]

2. Kerner, D.A.; Thomas, S.J. Resilience Attributes of Social-Ecological Systems: Framing Metrics for Management. Resources 2014, 3, 672-702. [CrossRef]

3. Walker, B.; Holling, C.S.; Carpenter, S.R.; Kinzig, A. Resilience, Adaptability and Transformability in Social-ecological Systems. Ecol. Soc. 2004, 9, 5. Available online: http://www.ecologyandsociety.org/vol9/ iss2/art5/ (accessed on 23 May 2016). [CrossRef]

4. Davidson, J.L.; Jacobson, C.; Lyth, A.; Dedekorkut-Howes, A.; Baldwin, C.L.; Ellison, J.C.; Holbrook, N.J.; Howes, M.J.; Serrao-Neumann, S.; Smith, T.F.; et al. Interrogating resilience: Toward a typology to improve its operationalization. Ecol. Soc. 2016, 21, 27. [CrossRef]

5. Holling, C.S. Understanding the Complexity of Economic, Ecological, and Social Systems. Ecosystems 2001, 4, 390-405. [CrossRef]

6. Resilience Alliance. Assessing and Managing Resilience in Social-Ecological Systems: A Practitioners Workbook. 2007. Available online: https://www.resalliance.org/index.php/resilience_assessment (accessed on 19 July 2019).

7. Folke, C.; Carpenter, S.R.; Walker, B.; Scheffer, M.; Chapin, T.; Rockström, J. Resilience thinking: Integrating resilience, adaptability and transformability. Ecol. Soc. 2010, 15, 20. Available online: http://www. ecologyandsociety.org/vol15/iss4/art20/ (accessed on 23 May 2016). [CrossRef]

8. Folke, C. Resilience (Republished). Ecol. Soc. 2016, 21, 44. [CrossRef]

9. Biggs, R.; Gordon, L.; Raudsepp Hearne, C.; Schlüter, M.; Walker, B. Principle 3. Manage slow variable and feedbacks. In Principles for Building Resilience: Sustaining Ecosystem Services in Socio-Ecological Systems; Biggs, R., Schlüter, M., Schoon, M.L., Eds.; Cambridge University Press: Cambridge, UK, 2015; pp. $105-141$.

10. Quinlan, A.E.; Berbés-Blázquez, M.; Haider, J.L.; Peterson, G.D. Measuring and assessing resilience: Broadening understanding through multiple disciplinary perspectives. J. Appl. Ecol. 2015, 1-11. [CrossRef]

11. Carpenter, S.; Westley, F.; Turner, M.G. Surrogates for Resilience of Social-Ecological Systems. Ecosystems 2005, 8, 941-944. [CrossRef]

12. Resilience Alliance. Assessing resilience in social-ecological systems: Workbook for Practitioners. 2010. Available online: http://www.resalliance.org/3871.php (accessed on 19 July 2019).

13. Carpenter, S.; Walker, B.; Anderies, J.M.; Abel, N. From Metaphor to Measurement: Resilience of What to What? Ecosystems 2001, 4, 765-781. [CrossRef]

14. Walker, B.; Salt, D. Resilience Practice, Building Capacity to Absorb Disturbance and Maintain Function; Island Press: Washington, DC, USA, 2012.

15. Turner, B.L.; Kasperson, R.E.; Matson, P.A.; McCarthy, J.J.; Corell, R.W.; Christensen, L.; Selin, N.E.; Kasperson, N.X.; Luers, A.L.; Schiller, A.; et al. A framework for vulnerability analysis in sustainability science. Proc. Natl. Acad. Sci. USA 2003, 100, 8074-8079. [CrossRef] [PubMed]

16. Salvia, R.; Quaranta, G. Adaptive Cycle as a Tool to Select Resilient Patterns of Rural Development. Sustainability 2015, 7, 11114-11138. [CrossRef]

17. Marschke, M.J.; Berkes, F. Exploring Strategies that Build Livelihood Resilience: A Case from Cambodia. Ecol. Soc. 2006, 11, 42. Available online: http://www.ecologyandsociety.org/vol11/iss1/art42/ (accessed on 23 May 2016). [CrossRef]

18. Tyler, S.; Moench, M. A framework for urban climate resilience. Clim. Dev. 2012, 4, 311-326. [CrossRef]

19. Davidson, J.L.; van Putten, I.E.; Leith, P.; Nursey-Bray, M.; Madin, E.M.; Neil, J. Toward Operationalizing Resilience Concepts in Australian Marine Sectors Coping with Climate Change. Ecol. Soc. 2013, 18, 4. [CrossRef]

20. Brand, F. Critical natural capital revisited: Ecological resilience and sustainable development. Ecol. Econ. 2009, 68, 605-612. [CrossRef]

21. O'Connell, D.; Walker, B.; Abel, N.; Grigg, N. The Resilience, Adaptation and Transformation Assessment Framework: From Theory to Application. 2015. Available online: http: //www.stapgef.org/sites/default/files/stap/wp-content/uploads/2015/03/CSIRO-STAP-ResilienceAdaptation-Transformation-Assessment-Framework-Report.pdf (accessed on 19 July 2019). 
22. Walker, B.; Salt, D. Resilience Thinking. Sustaining Ecosystems and People in a Changing World; Island Press: Washington, DC, USA, 2006.

23. UNDP. Community Based Resilience Assessment (CoBRA) Conceptual Framework and Methodology. 2013. Available online: https://www.undp.org/content/dam/undp/library/Environment $\% 20$ and $\%$ 20Energy/sustainable\%20land\%20management/CoBRA/CoBRRA_Conceptual_Framework.pdf (accessed on 19 July 2019).

24. Ellis, F. Rural Livelihoods and Diversity in Developing Countries; Oxford University Press: Cary, NC, USA, 2000.

25. Díaz, S.; Demissew, S.; Carabias, J.; Joly, C.; Lonsdale, M.; Ash, N.; Larigauderie, A.; Arico, S.; Bartuska, A.; Zlatanova, D.; et al. The IPBES Conceptual Framework-Connecting nature and people. Curr. Opin. Environ. Sustain. 2015, 14, 1-16. [CrossRef]

26. García-Ferrando, M. Socioestadística, Introducción a la Estadística en Sociología; Alianza Editorial: Madrid, Spain, 2008.

27. Holling, C.S. Resilience and stability of ecological systems. Annu. Rev. Ecol. Syst. 1973, 4, 1-23. [CrossRef]

28. Eakin, H.; Benessaiah, K.; Barrera, J.F.; Cruz-Bello, G.M.; Morales, H. Livelihoods and landscapes at the threshold of change: Disaster and resilience in a Chiapas coffee community. Reg. Environ. Chang. 2012, 12, 475-488. [CrossRef]

29. Altieri, M.A.; Nicholls, C.I. Agroecología y resiliencia al cambio climático: Principios y consideraciones metodológicas. Agroecología 2013, 8, 7-20.

30. Wang, S.H.; Huang, S.L.; Budd, W.W. Resilience analysis of the interaction of between typhoons and land use change. Landsc. Urban Plan. 2012, 106, 303-310. [CrossRef]

31. Ifejika-Speranza, C.; Wiesmann, U.; Rist, S. An indicator framework for assessing livelihoods resilience in the context of social-ecological dynamics. Glob. Environ. Chang. 2014, 28, 109-119. [CrossRef]

32. Berbés-Blázquez, M.; Mitchell, C.L.; Burch, S.L.; Wandel, J. Understanding climate change and resilience: Assessing strengths and opportunities for adaptation in the Global South. Clim. Chang. 2017, 141, 227-241. [CrossRef]

33. Schwarz, A.M.; Bene, C.; Bennett, G.; Boso, D.; Hilly, Z.; Paul, C.; Posala, R.; Sibiti, S.; Andrew, N. Vulnerability and resilience of remote rural communities to shocks and global changes: Empirical analysis from Solomon Islands. Glob. Environ. Chang. 2011, 21, 13. [CrossRef]

34. IUCN. A Guiding Toolkit for Increasing Climate Change Resilience. 2014. Available online: https://www.iucn.org/sites/dev/files/import/downloads/iucn_report_3_.pdf (accessed on 19 July 2019).

35. Montalba, R.; García, M.; Altieri, M.; Fonseca, F.; Vieli, L. Utilización del Índice Holístico de Riesgo (IHR) como medida de resiliencia socioecológica a condiciones de escasez de recursos hídricos. Aplicación en comunidades campesinas e indígenas de la Araucanía, Chile. Agroecología 2013, 8, 63-70.

36. Blythe, J.L. Resilience and social thresholds in small-scale fishing communities. Sustain. Sci. 2014, 10, 157-165. [CrossRef]

37. Bergamini, N.; Dunbar, W.; Eyzaguirre, P.; Ichikawa, K.; Matsumoto, I.; Mijatovic, D.; Morimoto, Y.; Remple, N.; Salvemini, D.; Vernooy, R.; et al. Toolkit for the Indicators of Resilience in Socio-ecological Production Landscapes and Seascapes. 2014. Available online: https://www.bioversityinternational.org/fileadmin/_migrated/uploads/tx_news/Toolkit_for_the_ indicators_of_iesilience_in_socio-ecological_production_landscapes_and_seascapes_1844.pdf (accessed on 19 July 2019).

38. Quaranta, G.; Salvia, R. An Index to measure rural diversity in the light of rural resilience and rural development debate. Eur. Countrys. 2014, 2, 161-178. [CrossRef]

39. DasGupta, R.; Shaw, R. An indicator based approach to assess coastal communities' resilience against climate related disasters in Indian Sundarbans. J. Coast. Conserv. 2015, 19, 85-101. [CrossRef]

40. Anderies, J.M.; Walker, B.; Kinzig, A.P. Fifteen Weddings and a Funeral: Case Studies and Resilience-based Management. Ecol. Soc. 2006, 11, 21. [CrossRef]

41. Sterk, M.; A van de Leemput, I.; Peeters, V. How to conceptualize and operationalize resilience in socio-ecological systems? Curr. Opin. Environ. Sustain. 2017, 28, 108-113. [CrossRef]

42. Nemec, K.; Chan, J.; Hoffman, C.; Spanbauer, T.; Hamm, J.; Allen, C.; Hefley, T.; Pan, D.; Shrestha, D. Assessing Resilience in Stressed Watersheds. Ecol. Soc. 2014, 19, 34. [CrossRef] 
43. Walker, B.; Gunderson, L.; Kinzig, A.; Folke, C.; Carpenter, S.; Schultz, L. A handful of heuristics and some propositions for understanding resilience in social-ecological systems. Ecol. Soc. 2006, 11, 13. Available online: http://www.ecologyandsociety.org/vol11/iss1/art13/ (accessed on 23 May 2016). [CrossRef]

44. Liu, J.; Dietz, T.; Carpenter, S.; Folke, C.; Alberti, M.; Redman, C.; Schneider, S.H.; Ostrom, E.; Pell, A.N.; Provencher, W.; et al. Coupled human and natural systems. Ambio 2007, 36, 639-649. [CrossRef]

45. IPCC. Summary for Policymakers. Climate Change 2014: Impacts, Adaptation and Vulnerability - Contributions of the Working Group II to the Fifth Assessment Report. 2014. Available online: https://www.ipcc.ch/report/ar5/wg2/ (accessed on 19 July 2019).

46. FAO. Resilient Livelihoods, Disaster Risk Reduction for Food and Nutrition Security. 2013. Available online: http://www.fao.org/3/a-i3270e.pdf (accessed on 19 July 2019).

47. Eakin, H.; Lemos, M.C.; Nelson, D.R. Differentiating capacities as a means to sustainable climate change adaptation. Glob. Environ. Chang. 2014, 27, 1-8. [CrossRef]

48. Sok, S.; Yu, X. Adaptation, resilience and sustainable livelihoods in the communities of the Lower Mekong Basin, Cambodia. Int. J. Water Resour. Dev. 2015, 31, 575-588. [CrossRef]

49. Santos-Prado, D.; Seixas, C.S.; Berkes, F. Looking back and looking forward: Exploring livelihood change and resilience building in a Brazilian coastal community. Ocean Coast. Manag. 2015, 113, 29-37. [CrossRef]

50. Fletcher, C.; Miller, C. Operationalizing Resilience in Australian and New Zealand Agroecosystems. 2006. Available online: file://Users/user/Downloads/355-1821-1-PB.pdf (accessed on 19 July 2019).

51. Cumming, G.S.; Barnes, G.; Perz, S.; Schimink, M.; Sieving, K.E.; Southworth, J.; Binford, M.; Holt, R.D.; Sticker, C.; Van Holt, T. An Exploratory Framework for the Empirical Measurement of Resilience. Ecosystems 2005, 8, 975-987. [CrossRef]

52. Bueno, N.; Basurto, X. Resilience and collapse of artisanal fisheries: A system dynamics analysis of a shellfish fishery in the Gulf of California, Mexico. Sustain. Sci. 2009, 4, 139-149. [CrossRef]

53. Bennett, E.M.; Cumming, G.S.; Peterson, G.D. A Systems Model Approach to Determining Resilience Surrogates for Case Studies. Ecosystems 2005, 8, 945-957. [CrossRef]

54. Walker, B.; Abel, N.; Anderies, J.; Ryan, P. Resilience, Adaptability, and Transformability in the Goulburn-Broken Catchment, Australia. Ecol. Soc. 2009, 14, 12. [CrossRef]

55. Kim, M.; You, S.; Chon, J.; Lee, J. Sustainable Land-Use Planning to Improve the Coastal Resilience of Social-Ecological Landscape. Sustainability 2017, 9, 1086. [CrossRef]

56. Rasch, S.; Heckelei, T.; Storm, H.; Oomen, R.; Naumann, C. Multi-scale resilience of communal rangeland system in South Africa. Ecol. Econ. 2017, 131, 129-138. [CrossRef]

57. Saxena, A.; Guneralp, B.; Bailis, R.; Yohe, G.; Oliver, C. Evaluating the resilience of forest dependent communities in Central India by combining the sustainable livelihoods framework and the cross scale resilience analysis. Curr. Sci. 2016, 110, 1195-1207. [CrossRef]

58. Dearing, J.A. Landscape change and resilience theory: A palaeoenvironmental assessment from Yunnan, SW China. Holocene 2008, 18, 117-127. [CrossRef]

59. Forbes, B.C.; Stammler, F.; Kumpula, T.; Meschtyb, N.; Pajunen, A.; Kaarlejärvi, E. High resilience in the Yamal-Nenets social-ecological system, West Siberian Arctic, Russia. Proc. Natl. Acad. Sci. USA 2009, 106, 22041-22048. [CrossRef] [PubMed]

60. Merritt, W.; Patch, B.; Reddy, R.; Syme, G. Modeling livelihoods and households resilience to droughts using Bayesian networks. Environ. Dev. Sustain. 2016, 18, 315-346. [CrossRef]

61. Uy, N.; Takeuchi, Y.; Shaw, R. Local adaptation for livelihood resilience in Albay, Philippines. Environ. Hazards 2011, 10, 139-153. [CrossRef]

62. Kotzee, I.; Reyers, B. Piloting a social-ecological index for measuring flood resilience: A composite index approach. Ecol. Indic. 2016, 60, 45-53. [CrossRef]

63. Suárez, M.; Gómez-Baggethun, E.; Benayas, J.; Tilbury, D. Towards an Urban Resilience Index: A Case Study in 50 Spanish Cities. Sustainability 2016, 8, 774. [CrossRef]

64. Cabell, J.F.; Oelofse, M. An indicator framework for assessing agroecosystem resilience. Ecol. Soc. 2012, 17, 18. [CrossRef]

65. Ekblom, A. Livelihood security, vulnerability and resilience: A historical analysis of Chibuene, Southern Mozambique. Ambio 2012, 41, 479-489. [CrossRef] [PubMed]

66. Ross, H.; Berkes, F. Research Approaches for Understanding, Enhancing, and Monitoring Community Resilience. Soc. Nat. Resour. 2014, 27, 787-804. [CrossRef] 
67. Dakos, V.; Carpenter, S.R.; van Nes, E.H.; Scheffer, M. Resilience indicators: Prospects and limitations for early warnings of regime shifts. Philos. Trans. R. Soc. B 2015, 370. [CrossRef]

68. Moore, C.; Grewar, J.; Cumming, G. Quantifying network resilience: comparison before and after a major perturbation shows strengths and limitations of networks metrics. J. Appl. Ecol. 2015, 1-10. [CrossRef]

69. Fleischman, F.; Boenning, K.; Garcia-Lopez, G.; Mincey, S.; Schmitt-Harsh, M.; Daedlow, K.; Lopez, M.; Basurto, X.; Fischer, B.; Ostrom, E. Disturbance, Response, and Persistence in Self-Organized Forested Communities: Analysis of Robustness and Resilience in Five Communities in Southern Indiana. Ecol. Soc. 2010, 15, 9. Available online: http://www.ecologyandsociety.org/vol15/iss4/art9/ (accessed on 23 May 2016). [CrossRef]

70. Allen, C.; Gunderson, L.; Johnson, A. The Use of Discontinuities and Functional Groups to Assess Relative Resilience in Complex Systems. Ecosystems 2005, 8, 958-966. [CrossRef]

71. Baral, N.; Stern, M. Capital stocks and organizational resilience in the Annapurna Conservation Área, Nepal. Soc. Nat. Resour. 2011, 24, 1011-1026. [CrossRef]

72. Hossain-Khan, M. Effects of Change In Land-Use And Natural Disasters On Social-Ecological Resilience And Vulnerabilities In Coastal Bangladesh. Master's Thesis, Norwegian University of Life Sciences, Ås, Norway, 2012.

73. Córdoba-Vargas, C.; León-Sicard, T. Resiliencia de sistemas agrícolas ecológicos y convencionales frente a la variabilidad climática en Anolaima (Cundinamarca-Colombia). Agroecología 2013, 8, 21-32.

74. Wilson, S.; Pearson, L.; Kashima, Y.; Lusher, D.; Pearson, C. Separating Adaptive Maintenance (Resilience) and Transformative Capacity of Social-Ecological Systems. Ecol. Soc. 2013, 18, 22. [CrossRef]

75. Cardoso, M.B.; Ladio, A.H.; Lozada, M. Fuelwood consumption patterns and resilience in two rural communities of the northwest Patagonia steppe, Argentina. J. Arid Environ. 2013, 98, 146-152. [CrossRef]

76. Henao-Salazar, A. Propuesta metodológica de medición de la resiliencia agroecológica en sistemas socio-ecológicos: un estudio de caso en los Andes Colombianos. Agroecología 2013, 8, 85-91.

77. Tittonell, P. Livelihood strategies, resilience and transformability in African agroecosystems. Agric. Syst. 2014, 126, 3-14. [CrossRef]

78. Moshy, V.; Bryceson, I.; Mwaipopo, R. Social-ecological Changes, Livelihoods and Resilience Among Fishing Communities in Mafia Island Marine Park, Tanzania. Forum Dev. Stud. 2015, 42, 529-553. [CrossRef]

79. Polanco-Echeverry, D.; Álvarez-Salas, L.; Ríos-Osorio, L. Proposed Methodology for Research Into the Socioecological Resilience of Agroecosystems. Trop. Subtrop. Agroecosyst. 2015, 18, 207-219.

80. Zhang, C.; Li, Y.; Zhu, X. A Social-Ecological Resilience Assessment and Governance Guide for Urbanization Processes in East China. Sustainability 2016, 8, 1101. [CrossRef]

81. Linständer, A.; Kuhn, A.; Naumann, C.; Rasch, S.; Sandhage-Hogmann, A.; Amelung, W.; Jordaan, J.; Du Preez, B.; Bolling, M.M. Assessing the resilience of real-world social-ecological system: Lessons from a multidisciplinary evaluation of South African pastoral system. Ecol. Soc. 2016, 21, 35. [CrossRef]

82. Cetinkaya Ciftciouglu, G. Assessment of resilience of social-ecological production landscapes and seascapes: A case study from Lefke Region of North Cyprus. Ecol. Indic. 2016, 73, 128-138. [CrossRef]

83. Tenza, A.; Pérez, I.; Martínez-Fernández, J.; Giménez, A. Understanding the decline and resilience loss of a long-lived social-ecological system: Insights from system dynamics. Ecol. Soc. 2017, 22, 15. [CrossRef]

(C) 2019 by the authors. Licensee MDPI, Basel, Switzerland. This article is an open access article distributed under the terms and conditions of the Creative Commons Attribution (CC BY) license (http://creativecommons.org/licenses/by/4.0/). 